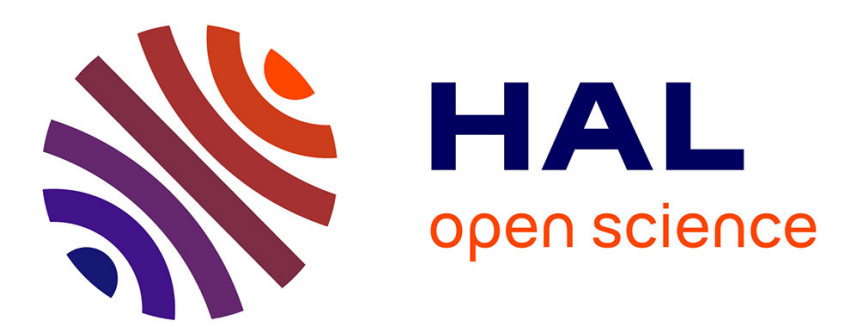

\title{
Effects of in vivo exposure to tritium: a multi-biomarker approach using the fathead minnow, Pimephales promelas
}

Beatrice Gagnaire, Isabelle Gosselin, Amy Festarini, Stephanie Walsh, Isabelle Cavalie, Christelle Adam-Guillermin, Claire Della-Vedova, F Farrow, San Bog Kim, A Shkarupin, et al.

\section{To cite this version:}

Beatrice Gagnaire, Isabelle Gosselin, Amy Festarini, Stephanie Walsh, Isabelle Cavalie, et al.. Effects of in vivo exposure to tritium: a multi-biomarker approach using the fathead minnow, Pimephales promelas. Environmental Science and Pollution Research, 2020, 27 (27), pp.3612-3623. 10.1007/s11356-018-3781-5 . hal-03118122

\section{HAL Id: hal-03118122 \\ https://hal.science/hal-03118122}

Submitted on 21 Jan 2021

HAL is a multi-disciplinary open access archive for the deposit and dissemination of scientific research documents, whether they are published or not. The documents may come from teaching and research institutions in France or abroad, or from public or private research centers.
L'archive ouverte pluridisciplinaire $\mathbf{H A L}$, est destinée au dépôt et à la diffusion de documents scientifiques de niveau recherche, publiés ou non, émanant des établissements d'enseignement et de recherche français ou étrangers, des laboratoires publics ou privés. 
7 Authors:

8 Beatrice Gagnaire ${ }^{* 1}$, Isabelle Gosselin ${ }^{2}$, Amy Festarini ${ }^{2}$, Stephanie Walsh ${ }^{2}$, Isabelle Cavalié ${ }^{1}$, 9 Christelle Adam-Guillermin ${ }^{1}$, Claire Della-Vedova ${ }^{3}$, Francesca Farrow ${ }^{2}$, Sang Bog Kim², Alexi 10

\section{Pimephales promelas}

\section{Effects of in vivo expos ure to tritium: a multi-biomarker approach using the fathead minnow,}

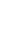

(

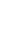

Shkarupin $^{2}$, Hui Qun Chen ${ }^{2}$, Danielle Beaton ${ }^{2}$ and Marilyne Stuart ${ }^{2}$

11

2

\section{Affiliation:}

${ }^{1}$ Institut de Radioprotection et de Sureté Nucléaire (IRSN), PSE-ENV/SRTE/LECO, Cadarache, Saint-Paul-lez-Durance 13115, France

17 Canadian Nuclear Laboratories (formerly Atomic Energy of Canada Limited), Chalk River 8 Laboratories, 286 Plant Road, Chalk River, ON K0J 1J0, Canada

$19{ }^{3}$ Institut de Radioprotection et de Sureté Nucléaire (IRSN), PSE-ENV/SRTE /LRTA, Cadarache, 20 Saint-Paul-lez-Durance 13115, France 21 22 


\section{Highlights}

- Following a previously published field investigation, this study aims to characterize tritium effects on fish health under controlled conditions in a laboratory setting.

- Fathead minnows were exposed to tritium activity concentrations up to $180,000 \mathrm{~Bq} / \mathrm{L}$.

- At the highest levels of exposure, tritium increased DNA damage and modulated the immune responses.

- Other markers were affected, including the neural system, oxidative stress and fatty acid composition.

- $\quad$ No effects are reported on the measured health indices and anti-oxidant activities.

\section{Abstract}

Tritium $\left({ }^{3} \mathrm{H}\right)$ is a radioactive isotope of hydrogen. In the environment, the most common form of tritium is tritiated water (HTO). However, tritium can also be incorporated into organic molecules, forming organically bound tritium (OBT). The present study characterized the effects of tritium on the health of the fathead minnow, Pimephales promelas. Fish were exposed to a gradient of HTO (activity concentrations of $12,000,25,000$ and $180,000 \mathrm{~Bq} / \mathrm{L}$ ) and OBT using food spiked with tritiated amino acids (OBT only, with an activity concentration of 27,000 Bq/L). A combined exposure condition where fish were placed in $25,000 \mathrm{~Bq} / \mathrm{L}$ water and received OBT through feed was also studied. Fish were exposed for 60 days, followed by a 60 day depuration period. A battery of health biomarkers were measured in fish tissues at seven time points throughout the 120 days required to complete the exposure and depuration phases. HTO and OBT were also measured in fish tissues at the same time points. Results showed effects of increasing tritium activity concentrations in water after 60 days of exposure. The internal dose rates of tritium, estimated from the tissue free-water tritium (TFWT) and OBT activity concentrations, reached a maximum of $0.65 \mu \mathrm{Gy} / \mathrm{h}$, which is relatively low considering background levels. No effects were observed on survival, fish condition, and metabolic indices (gonado-, hepato- and spleno- somatic indexes (GSI, HSI, SSI), RNA/DNA and proteins/DNA ratios). Multivariate analyses showed that several biomarkers (DNA damages, micronucleus (MN) frequency, brain acetylcholinesterase (AChE), lysosomal membrane integrity (LMI), phagocytosis activity and 

reactive oxygen species (ROS) production) were exclusively correlated with fish tritium internal dose rate, showing that tritium induced genotoxicity, as well as neural and immune responses. The results were compared with another study on the same fish species where fish were exposed to tritium and other contaminants in natural environments. Together with the field study, the present work provides useful data to identify biomarkers for tritium exposure and better understand modes of action of tritium on the fathead minnow.

60 Fathead minnow, Pimephales promelas; tritium internal dose rate; in vivo exposure; genotoxicity;

61 immune system response; oxidative stress response; neural response; fatty acid composition 


\section{Introduction}

Tritium $\left({ }^{3} \mathrm{H}\right)$ is a radioactive isotope of hydrogen. Naturally, the main source of tritium is from cosmic rays interacting with nitrogen in the atmosphere. Anthropogenically, it can be produced by the inreactor neutron activations of lithium, hydrogen and deuterium. Releases of tritium to the environment occur during normal functioning of nuclear power plants $\left(6.0 \times 10^{2}\right.$ to $4.0 \times 10^{3} \mathrm{kBq} / \mathrm{L}$ in the effluents in France and $<1.5 \times 10^{3} \mathrm{kBq} / \mathrm{L}$ in Canada) and nuclear fuel reprocessing plants $\left(10^{5} \mathrm{kBq} / \mathrm{L}\right.$ in the effluents in France) (HPA 2007, ASN 2010, OPG 2017). In both countries, the average tritium activity concentrations in receiving waters is very low at 1-4 Bq/L (ASN 2010, OPG 2017). The European and Canadian limits of tritium in water for human consumption are 0.1 and $7 \mathrm{kBq} / \mathrm{L}$, respectively (CNSC 2008, European_Union 2013). The International Thermonuclear Experimental Reactor (ITER) being built next to the Cadarache facility in France is an international research and engineering reactor due to come into service in 2030. It is expected that tritium releases to water and air will increase after this reactor is in operation (ASN 2010). In the environment, tritium is often found in the form of tritiated water (HTO), which can be incorporated into organic molecules, forming organically bound tritium (OBT) (Bogen et al. 1979). With the anticipated increase in tritium releases, there is a need to better understand tritium effects and particularly its toxic modes of action (ASN 2010).

Tritium is a low energy $\beta$ emitter with a half-life of 12.3 years, which causes high ionization density within a relatively small volume of matter (ASN 2010). Therefore, if enough tritium is ingested, the energy deposited could lead to health consequences. The toxicity of HTO has been studied on aquatic invertebrates and vertebrates (Adam-Guillermin et al. 2012). However, most of the studies reported acute toxicity effects using high dose rates (Real et al. 2004). Studies of the effects of tritium on fish have focused mostly on life-history endpoints linked to reproduction and development (Ichikawa \&Suyama 1974, Hyodo-Taguchi \&Etoh 1993, Sazykina \&Kryshev 2003). Therefore, there is a lack of data on biological effects induced on other biological scales and from chronic low levels of exposure, especially for aquatic vertebrates such as fish (Adam-Guillermin et al. 2012).

Chronic low levels of ionizing radiation exposure are not necessarily detrimental. In fact, they were previously shown to induce adaptive responses in fish and amphibians (Smith \&Moccia 2001, O'Neill- 
Mehlenbacher et al. 2007, Audette-Stuart et al. 2011, Audette-Stuart \&Yankovich 2011, Mothersill et al. 2014).

Tritium exposure has been shown to cause DNA breaks in aquatic invertebrates such as the marine mussel, Mytilus edulis (Hagger et al. 2005, Jha et al. 2005, 2006, Jaeschke et al. 2011), and in vertebrates including medaka (Suyama et al. 1981), fathead minnow (Gagnaire et al. 2017) and fish cells (Stuart et al. 2016). Molecular changes including DNA lesions, measured through the comet assay or micronucleus frequency (MN), a biomarker of chromosome damages, are referred to as genotoxicity markers because they indicate that ionizing radiation can affect cells and, if the DNA is left unrepaired, potentially have an effect on individual health or reproductive fitness. However, other kinds of effects were reported, such as the suppression of immune response in rainbow trout (Strand et al. 1982) as well as hormonal effects (Erickson 1971). Immune parameters such as phagocytosis (Fournier et al. 2000), lysosomal membrane integrity (Bado-Nilles et al. 2013), necrosis and reactive oxygen species production (ROS) (Gagnaire et al. 2014) have also been described as biomarkers that can be modified by several kinds of contaminants and can, therefore, be useful to assess the effects of tritium on aquatic vertebrates. If tritium can induce genotoxicity and immunotoxicity, it can be hypothesized that defense from oxidative stress, detoxification and general metabolism would respond to tritium exposure. Therefore, biomarkers of the antioxidant system (catalase (CAT), superoxide dismutase (SOD), glutathione peroxidase (GPX)) and also of the neural system (acetylcholinesterase (AChE)), which are commonly used in ecotoxicological studies (Sanchez \&Porcher 2009), may be modified by tritium. Moreover, the combined use of these biochemical markers, which are sensitive molecular and cellular indicators, and physiological markers (metabolic and somatic indices and fatty acid composition), which can show effects occurring at the individual level, is a promising way to relate responses observed at different levels of biological organization (Kerambrun et al. 2012).

The fathead minnow, Pimpehales promelas, a species of freshwater fish native to Canada, has shown to be tolerant to a wide range of water types. Moreover, this species has been used for toxicity testing since the 1960s (Environment_Canada 2011). In chronic low dose field tests (Gagnaire et al. 2017), fathead minnows were exposed to increasing HTO activity concentrations with cross-contamination with metals. It was found that several biomarkers related to immunity, DNA integrity, neural system 
118 and fatty acids presented changes that were correlated to fish internal tritium dose rate (Gagnaire et al.

119 2017). Therefore, this study was followed up with a controlled laboratory study in which fathead 120 minnows chronically exposed to low dose tritium spanning a similar range as that found at the field 121 sites were tested to assess genotoxic, immune and neurological responses. Two forms of tritium (HTO 122 and OBT) were assessed because tritium toxicity may also vary as a function of its chemical form 123 (Kim et al. 2015). Minnows were housed in aquaria and exposed over 60 days to water with a range of 124 HTO activity concentrations. Fish were given either non-tritiated feed or feed containing tritiated 125 amino acids. After this exposure period, all fish were maintained in non-tritiated water and given non126 tritiated food for another 60 day depuration period. Throughout the study, tritium internalization and 127 biomarkers for genotoxicity, oxidative stress, immunity and fitness were evaluated. 


\section{Material and Methods}

\section{$\underline{\text { Fish exposure }}$}

The laboratory study took place between September 2014 and January 2015. Approximately fivemonth old male fathead minnows $(3.93 \pm 0.13 \mathrm{~g}, 6.00 \pm 0.08 \mathrm{~cm})$ were received from Aquatics Research Organisms Inc. (Hampton, NH) and progressively allowed to adapt to the reconstituted water. During the study, the fish were kept in reconstituted water prepared by adding $11.0 \mathrm{~g}$ of calcium chloride $\left(\mathrm{CaCl}_{2}\right), 8.4 \mathrm{~g}$ of sodium bicarbonate $\left(\mathrm{NaHCO}_{3}\right), 3.0 \mathrm{~g}$ of magnesium sulfate $\left(\mathrm{MgSO}_{4}\right), 0.4 \mathrm{~g}$ of potassium chloride $(\mathrm{KCl})$ and $0.1 \mathrm{~g}$ of sodium bromide $(\mathrm{NaBr})$ to $100 \mathrm{~L}$ of deionized (reverse osmosis) water. The fish were housed in adjacent rooms that were maintained at $21 \pm 1^{\circ} \mathrm{C}$. The temperature in the tanks was $19.8 \pm 0.7^{\circ} \mathrm{C}$ due to frequent water changes; however, all treatment groups including controls were on the same water change schedule, so the potential effects of temperature changes were identical for all groups. Each $40 \mathrm{~L}$ or $20 \mathrm{~L}$ aquaria was equipped with circulation and filtration systems. Prior to being exposed to tritium, the fish were acclimated to the tank environment for 21 days, after which HTO was added to cover an activity concentration range from $<100 \mathrm{~Bq} / \mathrm{L}$ up to a maximum of $180,000 \mathrm{~Bq} / \mathrm{L}$. The aquaria were referred to as $\mathrm{C}$ (control), $12 \mathrm{~K}, 25 \mathrm{~K}$ and $180 \mathrm{~K}$ to reflect the nominal HTO tritium activity concentrations of 12,25 and $180 \mathrm{kBq} / \mathrm{L}$. The control aquaria were separated from the test aquaria in a different ventilated room to minimize cross-contamination.

To assess the effects of HTO through water and OBT through food on their own and combined, there were three different test conditions (HTO, OBT and a combination of the two), as previously used (Gagnaire et al. 2017). To measure the effects of only OBT, fish in dedicated tanks were fed commercial fish pellets spiked with tritiated amino acids (activity concentration of $27.8 \pm 5.7 \mathrm{kBq} / \mathrm{L}$ ) and the aquaria were filled with non-tritiated water (OBT). The HTO test group received non-tritiated commercial fish pellets, but were housed in water at activity concentrations of either 12,25 or 180 $\mathrm{kBq} / \mathrm{L}$. Finally, the third test group combined OBT and HTO, the fish were fed tritiated feed to an activity concentration of $27.8 \pm 5.7 \mathrm{kBq} / \mathrm{L}$ and the tanks contained water at $25 \mathrm{kBq} / \mathrm{L}$ of $\mathrm{HTO}$ (25KOBT).

The tritium exposure period was for 60 days, after which time the tritium activity concentrations returned to background values $(<100 \mathrm{~Bq} / \mathrm{L})$ for an additional 60-day depuration period in all tanks. 
Fish then received non-tritiated feed. The tank water was changed weekly and the fish were fed daily by adding an amount of commercial feed to achieve up to $1 \%$ of the total fish biomass in each tank. Water quality parameters for $\mathrm{pH}$, nitrogen compounds, temperature and hardness were regularly measured throughout the study. Fish mortality was recorded. Ten individual fish were randomly sampled from each exposure group for analysis of tritium, physical and biological markers at 60 days and at 120 days. In addition, 10 fish were measured (fork and standard lengths), the fish and their organs were weighed and a blood smear was prepared (to evaluate $\mathrm{MN}$ frequency) at day $0,15,30,60$, 75, 90 and 120, and tritium was measured in their tissues.

\section{$\underline{\text { Physico-chemical parameters }}$}

\section{HTO measurements}

HTO activity concentrations within the aquaria were measured weekly throughout the experiment. Water samples were collected from each aquarium and measured using Ultima Gold scintillation cocktail as previously described (Gagnaire et al. 2017). A standard of $145 \mathrm{~Bq} / \mathrm{mg}$ tritium was used to determine counter efficiency. Blank samples were also added. The detection limit was $50 \mathrm{~Bq} / \mathrm{L}$.

\section{Preparation of tritiated feed}

Fish were fed with Silver Cup $1.0 \mathrm{~mm}$ pellet fish feed from Martin Mills Inc. (Elmira, ON). The OBTspiked feed was prepared as previously described (Gagnaire et al. 2017). Non-tritiated control food was also prepared in the same way so that fish received the same food quality. The feed was analyzed for tritium and an average value of $27.8+/-5.7 \mathrm{kBq} . \mathrm{L}$ OBT was obtained.

\section{TFWT and OBT measurements and estimated dose rate in fish samples}

Ten minnows per treatment group were randomly collected for the analysis of tissue free-water tritium (TFWT) and OBT activity concentrations on days $0,15,30,60,75,90$ and 120 . Carcasses were also pooled (composite samples of 2-4 fish), and analyzed at days 0,60 and 120.

For TFWT measurements, frozen fresh samples were used as previously described (Gagnaire et al. 2017). The samples were counted for 100 minutes on a Tri-Carb 3110 TR LSC. The dilution factor 
was taken into account when the activity concentrations were calculated. The protocol for OBT measurement in animals is described in Kim et al. (2015) and Gagnaire et al. (2017). Samples of nontritiated Silver Cup feed were also prepared as described in Gagnaire et al. (2017).

Estimated internal dose rates were calculated from fish internal activity concentrations of TFWT and OBT using an internal dose coefficient (DC) of $5.38 \times 10^{-3} \mu \mathrm{Gy} / \mathrm{h}$ per Bq/g (EDEN software v2) (Beaugelin-Seiller 2016, Paquet \&Harrison 2018) under the hypothesis of a uniform repartition of tritium in tissues and using a radiation weighting factor of 3 in order to consider the relative biological effectiveness of tritium beta emissions compared to gamma radiation (Hunt et al. 2009), as previously described (Gagnaire et al. 2017). The weighting factor of 3 has been debated in the literature, but we chose to follow the same methodology as in the field experiment (Gagnaire et al. 2017) to allow for a direct comparison of results.

\section{$\underline{\text { Biological parameters }}$}

Fish dissection and sample collection

At several time points (D0, D60, and D120), ten fathead minnows per treatment group were randomly collected for analysis. For D0, 10 fish were analyzed before the beginning of the experiment.

Fathead minnows were measured for length, weighed and dissected for endpoint measurements. Fish were euthanized via rapid cooling followed by decapitation according to an animal care protocol approved by the Chalk River Laboratories (CRL) Animal Care Committee. Gonado-Somatic (GSI), Hepato-Somatic (HSI), Spleno-Somatic (SSI) indexes and Fulton's condition factor (K) were calculated as previously described (Amara et al. 2009, Gagnaire et al. 2017). Gender was confirmed during dissection.

Blood was used for micronuclei (MN) measurements. The brain, the muscle and the liver were used for enzymatic measurements. Other parts of the muscle and the liver were used for fatty acid composition analysis. Cell viability, phagocytosis, ROS levels and lysosomal membrane stability were assessed in spleen by flow cytometry within 24 hours of collection. Gonad samples were prepared, kept at $4^{\circ} \mathrm{C}$ overnight, and then used to conduct the viability and comet assay; another part of gonad 
samples was used to perform the RNA/DNA and protein/DNA determinations. Details are provided in Gagnaire et al. (2017).

Biological analyses

Cellular mortality, lysosomal membrane integrity (LMI), ROS basal and phorbol myristate acetate (PMA)-activated levels, and phagocytosis activity were determined using flow cytometry according to protocols described in Gagnaire et al. (2015a, 2017). The comet assay and the micronucleus frequency assay were performed as previously described (Festarini et al. 2016, Gagnaire et al. 2017). For enzymatic assays, brain, liver and muscle samples were homogenized immediately after sampling and the S9 fraction was frozen until analyses. All of the protocols for measuring hepatic GPX, CAT and SOD and brain and muscle AChE are presented in details in Gagnaire et al. (2017). Proteins, RNA and DNA quantification were performed on gonads as previously described (Gagnaire et al. 2017). Samples for fatty acids analysis were sent to Lipid Analytical Laboratories (Guelph, Ontario, Canada).

\section{$\underline{\text { Statistical analyses }}$}

Results are presented as mean \pm standard error (se). For the first raw analyses, normality of data was checked using the Shapiro-Wilk test and when not normal, data were Box-Cox transformed. Differences between conditions were tested with t-tests or ANOVA when the data were normal and with Kruskal-Wallis or Mann-Whitney Rank Sum tests when data were not normal. Analyses were performed using the STATISTICA Software version 12 (StatSoft, Inc., Tulsa, OK, USA), with significance at $\mathrm{p}<0.05$.

All multivariate analyses were computed using the R software (version 3.4.3) (R_Core_Team 2017) and RStudio environment (version 1.1.442) (RStudio_Team 2015). Simple linear regressions were used at D60 and D120 in order to assess the individual evolution of each biomarker as a function of increasing tritium exposure. Tritium exposure was characterized by a unique value for each condition (Control, 12K, 25K, OBT, 25KOBT, 180K). These values were the median of internal dose rates measured on individual fish (n comprised between 7 and 16). As the medians were highly dispersed ( 0.000258 to $0.65 \mu \mathrm{Gy} / \mathrm{h})$, they were $\log 10$ transformed in order to be used in regression models. 
240 Before performing the regression models, the linearity hypothesis was visually evaluated for each

241 biomarker using scatter plots of type "biomarker vs $\log 10$ of internal dose rate median" using the

242 ggplot2 package. This was satisfied for all comparisons. Finally, the significance of the linear

243 relationship was evaluated using a permutation test using the lmp function of the lmperm package.

244 


\section{Results}

$\underline{\text { Physico-chemical parameters }}$

HTO in water and TFWT in fish

At D15 and D30, we saw that TFWT values were consistently the same as the tank water HTO activity concentrations. At D60, however, the fish were transported, from the aquaria to the dissection room, in background water instead of tank water. For those fish, the measured TFWT were much lower because of the fast depuration rate. For dose calculation of the D60 fish, the TFWT was assumed to be the same as HTO of the tank water at the time of sampling.

Measured HTO activity concentrations in water are presented in Table 1. Average measured values were 63, 127, 10058, 21629, 20645 and $154314 \mathrm{~Bq} / \mathrm{L}$ for control, OBT, 12K, 25K, 25KOBT and 180K tanks, respectively. The OBT activity concentration in tritiated feed was $27.8 \pm 5.7 \mathrm{~Bq} / \mathrm{L}$ for both the OBT and 25KOBT conditions.

\section{TFWT, OBT and estimated dose rate in fish}

TFWT and OBT internal concentrations and estimated internal dose rates for all conditions and all time points are presented in Table 1. TFWT internal values followed the HTO activity concentrations in water (Control $<\mathrm{OBT}<12 \mathrm{~K}<25 \mathrm{KOBT}=25 \mathrm{~K}<180 \mathrm{~K})$. OBT internal concentrations were 24 to 50 times lower than TFWT internal concentrations at D60 (except for the OBT condition) and followed a different gradient $\quad($ Contro $<12 \mathrm{~K}<25 \mathrm{~K}<\mathrm{OBT}<25 \mathrm{KOBT}<180 \mathrm{~K})$. At $\mathrm{D} 120$, TFWT internal concentrations had long returned to background level. Note that for the OBT condition, TFWT stayed at background level throughout the study. At D120, OBT internal concentrations were 2 times lower than at D60 and were 1.9 to 17 times higher than TFWT internal concentrations.

OBT internal concentrations in $25 \mathrm{KOBT}$ compared to $25 \mathrm{~K}$ were 2.4 times higher at D60 and 1.5 times higher at D120 (Table 1).

The highest value of internal dose rate was $0.65 \mu \mathrm{Gy} / \mathrm{h}$, obtained for $180 \mathrm{~K}$ fish at D60 (Table 1).

The OBT formation and uptake was studied in fish exposed in the conditions $25 \mathrm{~K}$, OBT and 25KOBT

(Figure 1). The contribution of water and food to the OBT buildup was investigated over a period of 
272

273

274

275

276

277

278

279

280

281

282

283

284

285

286

287

288

289

290

291

292

293

294

295

296

297

298

299

60 days. It was noted that in the early stage of the exposure period (15 days), OBT formation (from water) was the major contributor to the buildup of OBT (Figure 1). Towards the end of the exposure period, however, OBT uptake (from food) was predominating (Figure 1). In contrast, the rate of loss of OBT in fish tissues over a 60 day depuration period showed a similar pattern regardless of the sourc e of the buildup (Figure 1).

\section{$\underline{\text { Biological parameters }}$}

Survival

The mortality rates were at a maximum of $4 \%$ between days 0 and 60 , and $2 \%$ between days 60 and 120, without any differences between groups (data not shown).

\section{$\underline{\text { Physiological responses }}$}

Results were analyzed in the context of researching effects of different conditions and type of exposure on biomarkers.

\section{Biological indices}

None of the evaluated biological indices (K, HSI, SSI, GSI) showed any significant differences among groups for all time points studied.

Values were significantly higher at D60 compared to D120 for $K\left(t\right.$ test, $\left.t_{1}=11.7, p=5 \times 10^{-21}\right)$. The fish weight to length ratio change for the last time point was not associated with a tritium exposure.

\section{RNA/DNA and proteins/DNA}

Analyses were performed only at D60. No significant differences among groups were shown for the different parameters.

\section{Fatty acids using C18:1 trans and SFA/MUFA as markers}

At D60, no differences were shown for parameters measured in the liver and for C18:1 trans in the muscle. The ratio SFA/MUFA in the muscle showed significant differences, with values for controls 
300

301

302

303

304

305

306

307

308

309

310

311

312

313

314

315

316

317

318

319

320

321

322

323

324

325

326

being lower than values for the 25KOBT group (Kruskal Wallis test, $\mathrm{H}_{5}=15.4, \mathrm{p}=0.008$ ) (Figure 2). Neither of the measured parameters presented differences among groups at D120. Values were significantly higher at D60 compared to D120 for SFA/MUFA in liver ( $t$ test, $t_{1}=2.05, p=0.042$ ).

\section{$\underline{\text { Genotoxic responses }}$}

Comet assay

At D60, both $25 \mathrm{KOBT}$ and $180 \mathrm{~K}$ groups presented significantly higher DNA damages compared to the control and OBT groups (Figure 3). At D120, a tendency for increased DNA damages was noted, with values higher for the OBT, the $25 \mathrm{KOBT}$ and the $180 \mathrm{~K}$ groups as compared to the $12 \mathrm{~K}$ and the 25K groups, and values for both these groups were higher than for the control group (Figure 3). Values were significantly higher at D60 compared to D120 (Mann-Whitney test $U, U_{1}=826, p=0.011$ ).

\section{Micronucleus frequency}

At D60, the $25 \mathrm{KOBT}$ and the $180 \mathrm{~K}$ groups presented significantly higher MN frequencies than all other groups (Figure 4). At D120, no differences between groups were found (Figure 4). Values were higher at $\mathrm{D} 60$ compared to $\mathrm{D} 120$ ( $\mathrm{t}$ test, $\mathrm{t}_{1}=2.17, \mathrm{p}=0.03$ ).

$\underline{\text { Immune, oxidative stress and neurotoxic responses }}$

Cell mortality presented no significant variations at either D60 or D120. LMI presented significant variations at D120: values were lower in the $12 \mathrm{~K}$ group compared to the $180 \mathrm{~K}$ group (Figure 5). At D60, the differences were not significant $(p=0.09)$, but a trend of higher values for the OBT, 25KOBT and $180 \mathrm{~K}$ groups as compared to the controls appeared. Values were higher at D60 compared to D120 ( $\mathrm{t}$ test, $\left.\mathrm{t}_{1}=4.7, \mathrm{p}=8 \times 10^{-6}\right)$.

The ROS production index presented no significant differences at D60. However, at D60, both basal and activated ROS levels were significantly lower in controls than in the $25 \mathrm{KOBT}$ and the $180 \mathrm{~K}$ groups (Kruskal Wallis test, $\mathrm{H}_{5}=22.1$ and 19.9, respectively; $\mathrm{p}=0.001$ ). At D120, the ROS production index values were significantly lower in the $180 \mathrm{~K}$ group compared to the control and the $12 \mathrm{~K}$ groups 
327

328

329

330

331

332

333

337

338

339

340

341

342

343

344

345

346

347

(one way ANOVA, $\mathrm{F}_{1}=3.28, \mathrm{p}=0.012$ ) (Figure 6). At D120, results for basal and activated ROS levels were globally the same as D60 (Kruskal Wallis test, $\mathrm{H}_{5}=22.6$ and 20.8, respectively; $\mathrm{p}=0.001$ ).

Phagocytosis activity presented no significant differences at D60. At D120, values were significantly higher in the $180 \mathrm{~K}$ group compared to controls (Figure 7).

None of the evaluated enzymatic activities (AChE in brain and muscle, SOD and GPX in brain and liver, CAT in liver) showed any significant differences among groups for all time points studied. Values were significantly higher at D60 compared to D120 for muscle AChE (t test, $t_{1}=6.9$, $\mathrm{p}=3.3 \times 10^{-10}$ ), and lower at D60 compared to D120 for brain AChE, GPX and SOD ( $t$ test, $\mathrm{t}_{1}=-4.32,-12.2$ and -5.9 , respectively; $\mathrm{p}=4.7 \times 10^{-5}, 2.8 \times 10^{-12}$ and $8.7 \times 10^{-8}$, respectively).

\section{Multivariate analyses}

The General Linear Models (GLM) allowed for the evaluation of the potential effects of tritium radiological dose rate in fish tissues.

The model showed that several parameters were positively or negatively correlated with fish tritium dose rate (Table 2). At D60, DNA damages $\left(\mathrm{F}_{1}=0.073, \mathrm{p}=2 \times 10^{-16}\right)$ and $\mathrm{MN}$ frequency $\left(\mathrm{F}_{1}=1.54\right.$, $\mathrm{p}=10^{-20}$ ) were positively correlated to dose rate. At D120, several parameters were positively correlated to tritium dose rate in fish tissues: DNA damages $\left(\mathrm{F}_{1}=0.11, \mathrm{p}=10^{-20}\right)$, brain AChE activity $\left(\mathrm{F}_{1}=0.42, \mathrm{p}=0.0224\right)$, spleen LMI $\left(\mathrm{F}_{1}=84.5, \mathrm{p}=0.0144\right)$, spleen phagocytosis activity $\left(\mathrm{F}_{1}=7.41\right.$, $\mathrm{p}=0.0014)$, spleen ROS activated and basal levels $\left(\mathrm{F}_{1}=377.8\right.$ and 387.1, $\mathrm{p}=0.0026$ and 0.0002 , respectively), whereas ROS index was negatively correlated $\left(\mathrm{F}_{1}=-0.32, \mathrm{p}=0.0158\right)$ (Table 2). 


\section{Discussion}

TFWT and OBT in fish tissues

As for the field study (Gagnaire et al. 2017), the increasing gradient of tritium activity concentration in the water was also found in fish tissues for TFWT and OBT at D60. After the beginning of depuration, when tritium was absent from the water, fish tissue TFWT was also rapidly depurated; however, OBT was still present in fish tissues even after 60 days of depuration (D120).

As previously discussed (Gagnaire et al. 2017), TFWT levels in fish tissues are assumed to match water levels, with theoretical concentration factors close to 1 (Melintescu et al. 2011). In our study, we saw equilibrium between TFWT and tank water HTO at D15 and D30. At those time points, concentration factors were between 0.76 and 0.81 , which is higher than the concentration factors obtained for the field study (Gagnaire et al. 2017). Moreover, exchangeable OBT is supposed to equilibrate with internalized TFWT, leading to an OBT/TFWT ratio close to 1 in aquatic organisms at equilibrium (Melintescu et al. 2011) and in fish (Smith et al. 2006). This was not the case in the present study. As for the field study (Gagnaire et al. 2017), this was expected as it takes time for OBT to accumulate in fish tissues and it also takes a long time for it to depurate (Kim et al. 2015). However, we used our data to evaluate HTO transfer and transformation of internalized TFWT in OBT because this is currently poorly documented (Melintescu \& Galeriu 2011).

\section{Origin of OBT accumulated in fish tissues}

OBT in fish can be formed from two different sources: water and food. To differentiate the sources we have used the terms formation and uptake. Firstly, formation is defined as the buildup of OBT through surrounding water by metabolism. Secondly, uptake is defined as the buildup of OBT through ingestion of OBT contained in the food.

Our results indicated that the food chain will be the main contributor to OBT buildup in fish under long-term exposure, such as natural environmental conditions around nuclear facilities. Once fish are no longer exposed to tritium, the depuration time for OBT would be expected to be similar regardless of the form of tritium exposure. 
A series of trout experiments conducted over 140 days, when fish were contaminated with HTO and/or OBT, reported that OBT was building up considerably faster in tissues when fish were receiving OBT spiked feed (assuming 25\% assimilation) compared to being exposed to the same HTO level in their tank water (Kim et al. 2013, Kim et al. 2015). This means that OBT uptake was a greater contributor compared to OBT formation. The rate of OBT build up was also found to change with the fish growth rate, with faster growth rates resulting in lower OBT activity concentration in tissues.

In the current study, the OBT activity in the feed represented a smaller fraction than the HTO in the water compared to the trout study. If the exposure conditions were mirrored, for a water HTO activity concentration of about $25 \mathrm{kBq} / \mathrm{L}$, fish would receive OBT in the feed of about $100 \mathrm{kBq} / \mathrm{L}$ (again assuming $25 \%$ of assimilation). In this study, however, for a HTO activity concentration of about 25 $\mathrm{kBq} / \mathrm{L}$, the fish were receiving feed at about $27 \mathrm{kBq} / \mathrm{L}$, which corresponds to about $7 \mathrm{kBq} / \mathrm{L}$ if $25 \%$ of assimilation is assumed. Despite this difference in study design, the results obtained in the current study agree well with the trout study results in the sense that, for chronic exposure, OBT contaminated feed also plays a predominant role in OBT buildup in the tissue.

\section{Effects on biological parameters}

No significant differences among groups for any of the assessed biological indices were found. Similarly, no effect of tritium was shown for either the RNA/DNA or proteins/DNA ratios in gonads and kidneys. Similar results were obtained after exposure of younger fathead minnows to tritium and other pollutants in a field experiment (Gagnaire et al. 2017). As several of these parameters are a direct or indirect indication of the metabolic growth rate of the organism (Amara et al. 2009), we could hypothesize that the dose rates were too low or that the duration of the experiment was not long enough to see an impact on these integrative indices.

In the present study, SFA/MUFA ratio in the muscle was not correlated to fish tritium dose rate. In the field study, the same ratio in liver and also C18:1 trans in muscle were positively correlated to fish tritium dose rate (Gagnaire et al. 2017). Ionizing radiation exposure was shown to modulate fatty acid composition, and the changes are known to be tissue-specific and influenced by diet (Nawar 1973, Audette-Stuart et al. 2012). In the field study, the dietary fatty acids intake differed from the laboratory 
study because the fish were feeding on organic matter suspended in the water column in addition to the provided feed. The differences noted between the field and the laboratory study may, therefore, reflect differences in diet. Our laboratory findings did not confirm laboratory results obtained in trout exposed to HTO where a decrease of SFA/MUFA ratio was observed in liver and muscle (Festarini et al. 2016). Muscle SFA/MUFA ratio cannot be considered as a direct indicator of tritium effects in fish.

The genotoxic biomarkers evaluated in this study presented significant differences in tritium exposed fish: DNA damages measured by the comet assay were positively correlated to tritium internal dose rates for both sampling times. The same result was obtained for MN frequency but only at D60. This result showed that the effect on $\mathrm{MN}$ frequency was reversible as they returned to background values at the end of the depuration period. These results suggest that OBT remaining in the tissues at D120 can induce DNA strand breaks in the gonad, but not MN frequency in the blood. However, it should be noted that while sperm cells turnover is really quick (a few days), the turnover of fish erythrocytes is longer (100-400 days) (Soldatov 2005). Damages on blood cells could therefore have been repaired at D120. The same results were obtained in the field experiment, with a reversible effect on MN frequency and non-reversible effects, within 60 days of depuration, on DNA damages (Gagnaire et al. 2017). Moreover, in the field study, both of these parameters were positively correlated with fish tritium dose rate (Gagnaire et al. 2017); in the present lab study, the same result was obtained for MN frequency at D60. The effects observed on these genotoxic biomarkers can therefore be related to tritium.

Tritium was previously shown to increase MN frequency and DNA damages in adult mussels exposed at $12.5 \mu \mathrm{Gy} / \mathrm{h}$ of HTO (Jha et al. 2005, 2006) and $79 \mu \mathrm{Gy} / \mathrm{h}$ of tritiated glycine (Jaeschke et al. 2011), doses 19 and 121 times higher, respectively, than the highest one estimated in our study, showing that fathead minnow is more sensitive to tritium than invertebrates considering DNA damages. Cytogenetic effects were also shown in medaka eggs and embryo-larvae of marine mussel, Mytilus edulis, exposed to high dose rates of tritium (Suyama et al. 1981, Hagger et al. 2005). DNA damages also increased after exposure of sticklebacks around former uranium mining sites (Le Guernic et al. 2016). Increased DNA damages were also shown after exposure of daphnids, Daphnia magna, to dose rates of gamma-rays as low as $7 \mu \mathrm{Gy} / \mathrm{h}$ (Parisot et al. 2015). Increased DNA damages were also shown 
after exposure of zebrafish larvae to $33 \mu \mathrm{Gy} / \mathrm{h}$ of gamma-rays (Gagnaire et al. 2015b) and $400 \mu \mathrm{Gy} / \mathrm{h}$ of tritium (Gagnaire et al, unpublished data). At $400 \mu \mathrm{Gy} / \mathrm{h}$, still on zebrafish larvae, the expression of genotoxic markers $h 2 a f x$ and $d d b 2$ involved in DNA repair were both induced in response to HTO exposure (Arcanjo et al., unpublished data). In the same way, DNA damages and MN frequency increased in fish cell lines exposed to tritium (Stuart et al. 2016). Gamma-H2AX was also correlated to tritium dose rate in the field experiment (Gagnaire et al. 2017). These results suggest the establishment of defense against DNA damage by the over-expression of DNA repair genes. Taken all together, these results confirm that radionuclides can induce genotoxicity and that the cells respond by upregulating DNA repair genes.

The immune system also responded to tritium exposure. The response was, however, often detected later in the study, mostly after the depuration period. At D120, LMI and phagocytosis activity were higher and ROS production index was lower in the 180K fish. LMI and phagocytosis activity were positively correlated with tritium dose rate in fish tissues at D120, while ROS index was negatively correlated with tritium dose rate in fish tissues. The same increase in LMI was found in the field study at both sampling times (Gagnaire et al. 2017). Even if LMI was shown to be affected by metals (BadoNilles et al. 2013), we could hypothesize that the effects observed on LMI were, in part, due to tritium. Contrary to the lab study findings, no statistically significant effects on phagocytosis were shown in the field study; however, this biomarker did correlate with the HTO conditions in the depuration period (Gagnaire et al. 2017). An increase of phagocytosis indicates an enhanced capacity of the organism to protect against infections, but could also lead to an increase of oxidative stress (Whyte 2007). Although ROS production was not investigated in the field study, the laboratory study showed that increased phagocytosis did not correlate with an increase in oxidative stress. It has been shown that tritium induced no effect on ROS production index in zebrafish larvae exposed to HTO; however, ROS activated level increased in HTO larvae after 4, 7 and 10 days of exposure to 280-380 $\mu \mathrm{Gy} / \mathrm{h}$ (Gagnaire et al, unpublished data). The ROS index was also shown to be affected by gamma radiation exposure (Gagnaire et al. 2015b). Tritium has been shown to negatively affect the primary immune response in juveniles of rainbow trout after 20 days of exposure to $83 \mu \mathrm{Gy} / \mathrm{h}$ (Strand et al. 1982), suggesting that the fish immune system seems to be an important target of tritium. 
In this study, none of the antioxidant parameters (SOD, CAT, GPX) showed any variations with

460

461

462

463

464

465

466

467

468

469

470

471

472

473

474

475

476

477

478

479

480

481

482

483

484

485

tritium concentrations, but brain AChE was correlated to fish tritium dose rates, as in the field study (Gagnaire et al. 2017). For the field study, SOD and CAT activities were also correlated to fish tritium dose rate, but at different time points depending on the organ (Gagnaire et al. 2017). However, in the field study, metals were also present in the water of the tested sites in addition to tritium. Many studies have shown that alterations of these parameters are mostly caused by metals or pesticides (Sanchez et al. 2005, Richetti et al. 2011). The fact that these activities presented variations in the presence of metals associated with tritium and not with tritium alone leads us to think that these markers are not suitable for the assessment of chronic low level tritium exposure in fish.

\section{Relationships between observed effects and tritium internal dose rate}

Research on the effects of tritium on fish has mostly addressed reproduction and fecundity. Strand et al. (1982) showed mortality and malformations in trout eggs after 21 days of HTO exposure at 12 $\mu \mathrm{Gy} / \mathrm{h}$ (total dose of $6 \mathrm{mGy}$ ). In medaka, the number of germ cells changed in embryos exposed to $7080 \mu \mathrm{Gy} / \mathrm{h}$ for 10 days (total dose of $1.7 \mathrm{~Gy}$ ) (Etoh \&Hyodo-Taguchi 1983), and the number of primary spermatogonia (Hyodo Taguchi \&Egami 1977), vertebral malformations and fecundity (Hyodo-Taguchi \&Etoh 1986, 1993) were affected at $1200 \mu \mathrm{Gy} / \mathrm{h}$ in adult fish exposed for 30 days (total dose of 864 mGy). In the puffer fish, Fugu niphobles, HTO induced a decrease of egg hatching at $12100 \mu \mathrm{Gy} / \mathrm{h}$ following a $130 \mathrm{~h}$ exposure period (total dose of $1.54 \mathrm{~Gy}$ ) (Ichikawa \&Suyama 1974). All of these observations were made at much higher levels than the doses studied in the present study. In fact, at D60, the highest dose rate calculated in our study was $0.65 \mu \mathrm{Gy} / \mathrm{h}$, which corresponds to a total dose of $936 \mu \mathrm{Gy}$.

The maximal dose rate studied in the laboratory setting was higher than the highest dose rate calculated in the field study. In the field study, over a 60 day exposure period, the total dose was $216 \mu$ Gy (Gagnaire et al. 2017). Both of these values are considerably lower than the studies reporting effects of tritium on fish. The values of dose rates observed in these field and laboratory studies were also lower than the benchmark used for ecosystem protection of $10 \mu \mathrm{Gy} / \mathrm{h}$ (Garnier-Laplace et al. 
486 2010). It follows that the low dose rates and cumulative doses studied were not expected to induce

487 deterministic effects on fathead minnows, and our observations are in agreement with this.

488 The minimum Low Observed Effect Dose Rate (LOEDR) for tritium has been shown to reach $4890.62 \mu \mathrm{Gy} / \mathrm{h}$ for invertebrate larval development and $12.1 \mu \mathrm{Gy} / \mathrm{h}$ on fish development (Adam490 Guillermin et al. 2012). The highest dose rate obtained in this study for 180K fish at D60 was 0.65 $491 \mu \mathrm{Gy} / \mathrm{h}, 18$ times lower than the LOEDR for fish development. As for the field study (Gagnaire et al. 492 2017), at this low dose rate, several biomarkers were found to be exclusively modulated by tritium 493 internal dose rate, including blood MN frequency (at D60), gonad comet tail moment, spleen LMI, 494 phagocytosis activity and ROS production, and muscle SFA/MUFA ratio (at D120).

495 


\section{Conclusion}

497 The present study aimed to evaluate the effects of HTO and OBT on P. promelas in laboratory conditions. Fish health was not affected by tritium exposure as no effects were shown on survival,

499

500

501

502

503

504

505

506

507

508

509

510

511

512

513

514

515

516

517 condition and physiological indices. Considering the low dose rates (maximum of $0.65 \mu \mathrm{Gy} / \mathrm{h}$ ), this result is not surprising, as the DCRL (Derived Consideration Reference Levels) in which deleterious effects are expected on young fish are supposed to be $4 \mathrm{mGy} / \mathrm{h}$ (ICRP 2008). However, at these low dose rates, several biomarkers were correlated with the internal tritium dose rate. Therefore, this study showed that tritium induced genotoxicity, neural and immune responses as we saw modulations of DNA damages, micronucleus frequency, brain AChE, lysosomal membrane integrity and phagocytosis activities. No effects were observed on SOD, CAT, GPX activities and RNA/DNA/protein ratios.

In this study, as no effects appeared on health indices, we can conclude that no adverse effect on fitness was shown at tritium concentrations 25 times and 1800 times higher than Canadian and European drinking water limits, respectively. This result indicates nonlinear dose-response relationships for these indices. Effects on these indices may be observed at higher tritium concentrations when the exposure threshold is reached.

When comparing our results with those obtained in another study using the same fish species exposed to tritium in natural environments also containing other contaminants, results were similar for several biomarkers: immune (phagocytosis activity, ROS production, lysosomal membrane integrity) and genotoxic parameters (MN frequency and DNA damages). Therefore, the multi-biomarker approach used in both of these studies allowed us to identify the most relevant biological pathways involved in response to tritium exposure in fathead minnows in laboratory and field settings, and consists in an interesting approach for the assessment of radionuclide effects in aquatic ecosystems. 
520 The authors are grateful for Jerry Piekarski at Lipid Analytical (University of Guelph) for performing

521 the lipid analysis. The authors also want to thank Matt Bond, Jennifer Olfert and Joanne Ball (CNL)

522 for carefully reviewing the manuscript.

523 
Figure 1: Relative OBT build up and loss patterns during exposure and depuration periods.

527 Figure 2: SFA/MUFA ratio in the muscle of fathead minnows at D60 and D120. Kruskal-Wallis test, $528 \mathrm{p}<0.01 ; \mathrm{a}<\mathrm{b}$.

529 Figure 3: Results of the comet assay, expressed as mean tail moment, obtained in the gonad of fathead minnows at D60 and D120. Kruskal-Wallis test, $\mathrm{p}<0.0001 ; \mathrm{a}<\mathrm{b}<\mathrm{c}<\mathrm{d}$.

Figure 4: Micronucleus frequency obtained from the blood of fathead minnows sampled at D60 and D120. Two-way ANOVA, $\mathrm{p}<0.0001 ; \mathrm{a}<\mathrm{b}$.

Figure 5: Lysosomal membrane integrity (LMI) expressed as mean fluorescence intensity (MFI), measured in the spleen of fathead minnows at D60 and D120. Two-way ANOVA, $\mathrm{p}<0.05 ; \mathrm{a}<\mathrm{b}$.

Figure 6: ROS index (ratio activated/basal ROS levels expressed as MFI) measured in the spleen of fathead minnows at D60 and D120. Two-way ANOVA, $\mathrm{p}<0.05 ; \mathrm{a}<\mathrm{b}$.

537 Figure 7: Phagocytosis activity expressed as percentage of cells containing three beads or more, measured in the spleen of fathead minnows at D60 and D120. Two-way ANOVA, $\mathrm{p}<0.001 ; \mathrm{a}<\mathrm{b}$. 
541

$542 \quad$ Figure 1

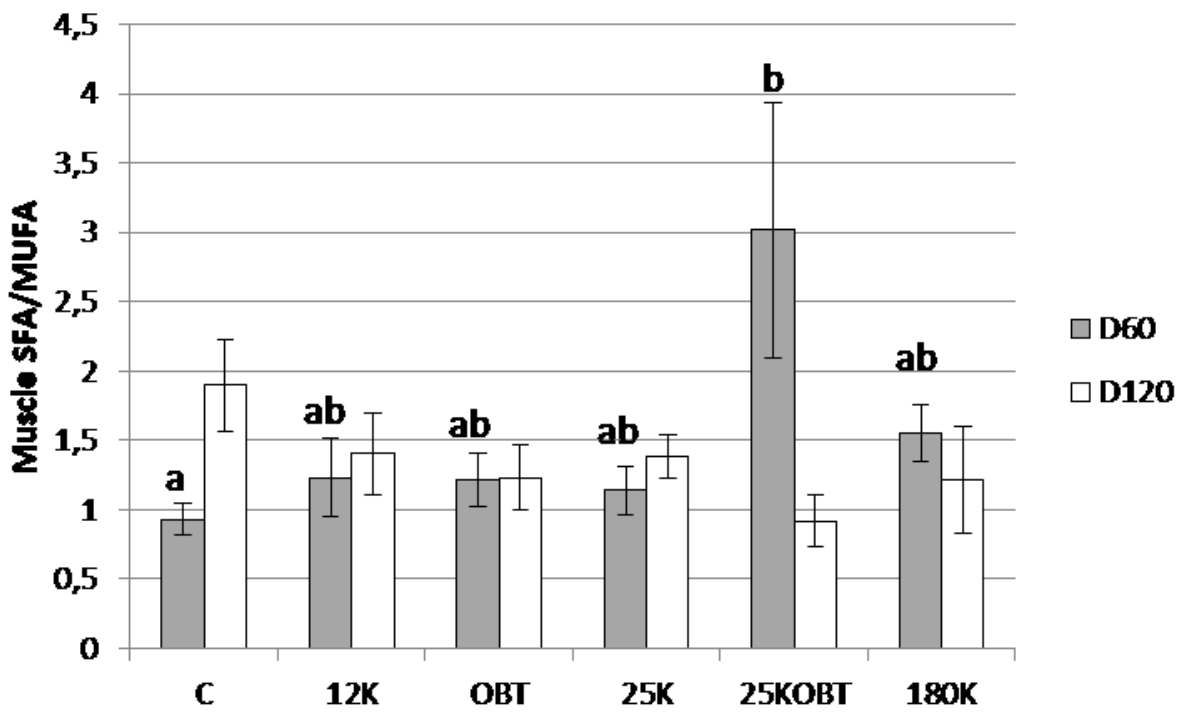

543

544 Figure 2

545

546

547

548

549

550

551 


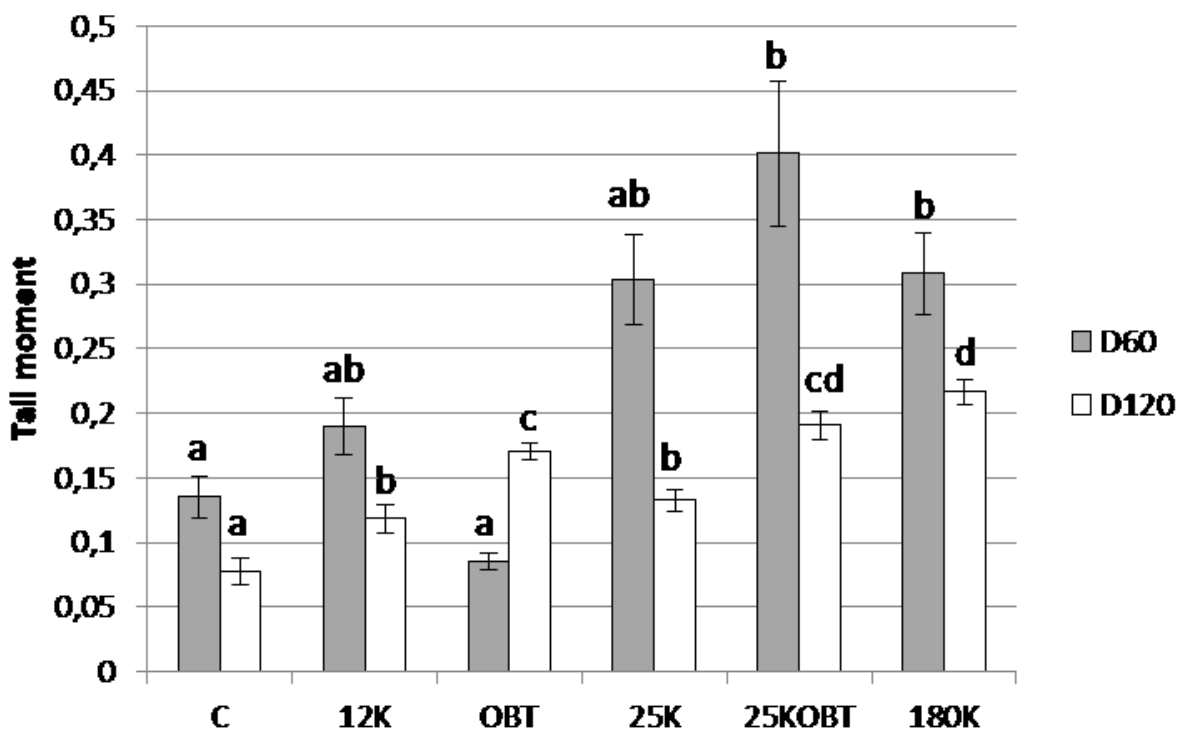

$553 \quad$ Figure 3

554

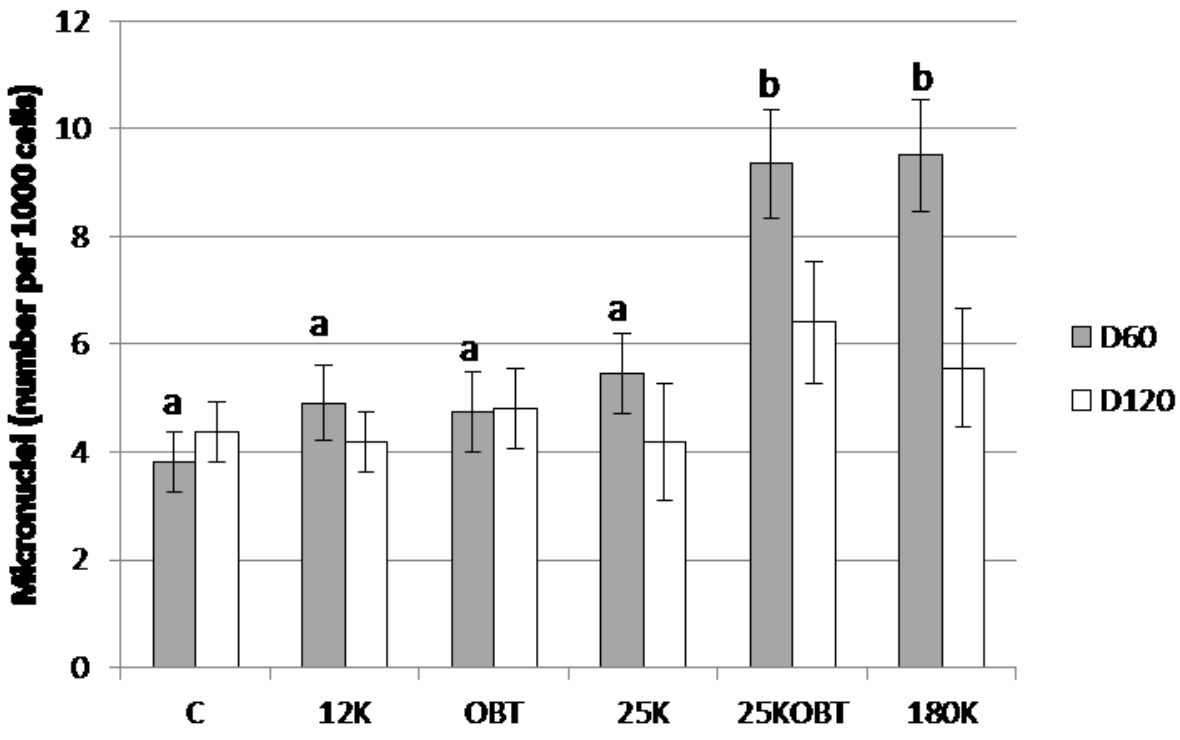

555

556 Figure 4

557

558

559

560

561

562 
563

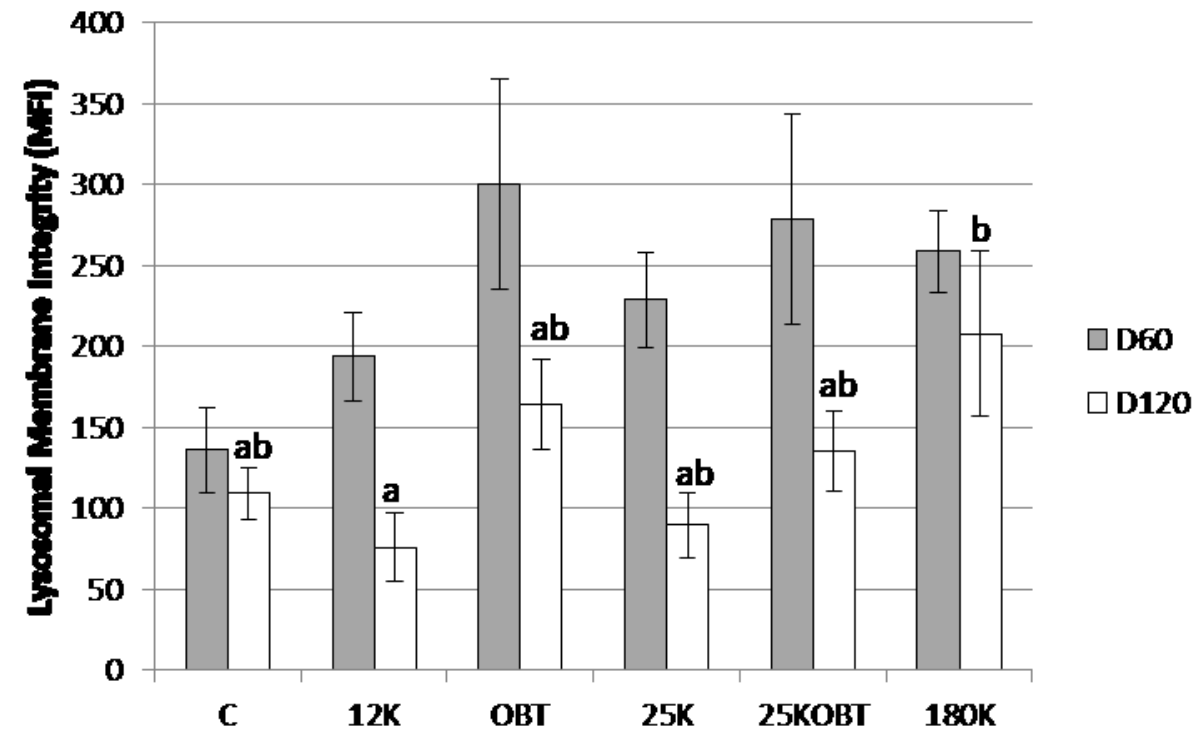

$564 \quad$ Figure 5

565

566

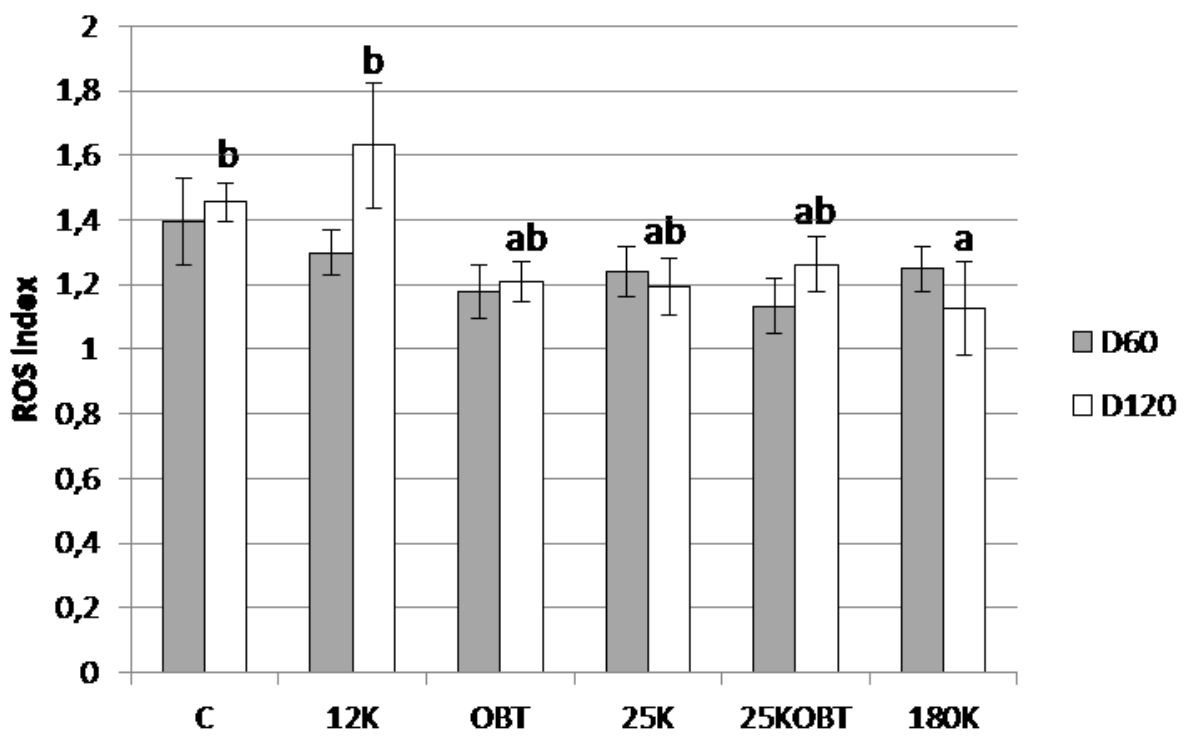

567 Figure 6

568

569

570

571

572 
573

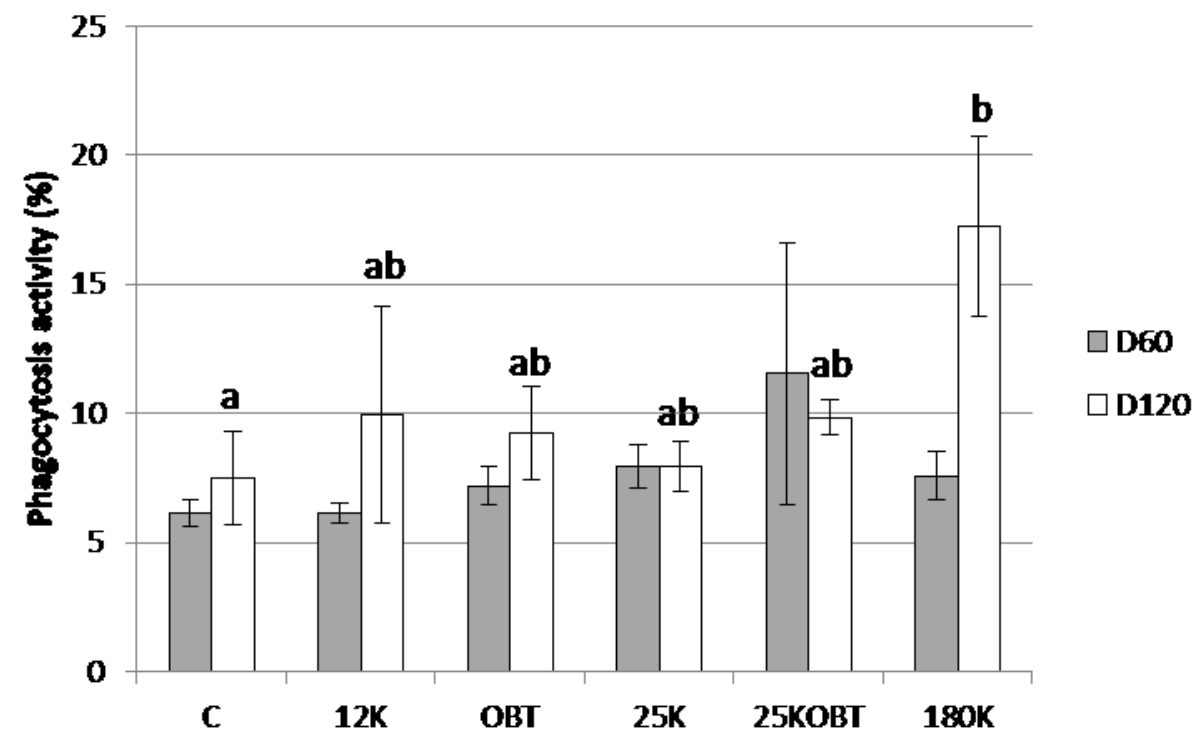

$574 \quad$ Figure 7

575

576 
Table 1: HTO water concentration, HTO and OBT activity concentrations (Bq/kg fresh) and associated estimated dose rate ( $\mu$ Gy/h) in fish during the experiment. <dl: less than detection limit. Values presented contain at least ten replicates $+/$ - standard error. The water equivalent factor (WEF) was calculated using our fish water content (Water content $=75 \%, \mathrm{WEF}=0.6$ ). At $\mathrm{D} 60$, concentration factor was not calculated because as fish were transported in background water instead of tank water, their measured TFWT were much lower because of the fast depuration rate. At D120, HTO water activity concentrations were either below or above DL; therefore, only one value corresponding to the mean of all values obtained is presented.

\begin{tabular}{|c|c|c|c|c|c|c|c|}
\hline \multirow[b]{2}{*}{ Time point } & \multirow[b]{2}{*}{ Condition } & \multirow{2}{*}{$\begin{array}{l}\text { HTO water } \\
\text { activity } \\
\text { concentration } \\
\text { Bq/L }\end{array}$} & \multicolumn{3}{|c|}{ Internal activity concentration } & \multirow{2}{*}{$\begin{array}{c}\text { Concentration } \\
\text { factor } \\
\text { (TFWT fish/HTO } \\
\text { water) }\end{array}$} & \multirow{2}{*}{$\begin{array}{c}\text { Estimated dose rate } \\
\begin{array}{c}\text { Total tritium }(3 H \mathrm{HR}) \\
\mu \mathrm{Gy} / \mathrm{h}\end{array}\end{array}$} \\
\hline & & & $\begin{array}{c}\text { TFWT } \\
\mathbf{B} \mathbf{p} / \mathbf{k g} \text { (fresh) }\end{array}$ & $\begin{array}{c}\text { OBT } \\
\text { Bq/kg (fresh) }\end{array}$ & $\begin{array}{c}\text { Total tritium } \\
\text { (TWWT+OBT) } \\
\text { Bq/kg (fresh) }\end{array}$ & & \\
\hline \multirow{6}{*}{ D60 } & C & 63 & $15+/-2$ & $22+/-5$ & $42+/-6$ & --- & $2.3 \mathrm{E}-04+/-\quad 3.2 \mathrm{E}-05$ \\
\hline & $12 \mathrm{~K}$ & $10058+/-1298$ & $8193+/-219$ & $192+/-13$ & $8396+/-227$ & --- & $4.5 \mathrm{E}-02+/-\quad 1,2 \mathrm{E}-03$ \\
\hline & $25 \mathrm{~K}$ & $21629+/-612$ & $16477+/-135$ & $292+/-10$ & $16780+/-142$ & --- & $9.0 \mathrm{E}-02+/-\quad 7,6 \mathrm{E}-04$ \\
\hline & OBT & $127+/-71$ & $29+/-3$ & $419+/-20$ & $452+/-19$ & --- & $2.4 \mathrm{E}-03+/-\quad 1,0 \mathrm{E}-04$ \\
\hline & $25 \mathrm{KOBT}$ & $20645+/-3033$ & $16748+/-669$ & $691+/-23$ & $17449+/-683$ & --- & $9.4 \mathrm{E}-02 \quad+/-\quad 3,7 \mathrm{E}-03$ \\
\hline & $180 \mathrm{~K}$ & $154314+/-6239$ & $118713+/-1141$ & $2377+/-99$ & $121153+/-1203$ & --- & $6.5 \mathrm{E}-01+/-\quad 6,5 \mathrm{E}-03$ \\
\hline \multirow{6}{*}{ D120 } & $\mathrm{C}$ & $<100$ & $38+/-13$ & $31+/-1$ & $69+/-13$ & 0.49 & $3.7 \mathrm{E}-04+/-6.9 \mathrm{E}-05$ \\
\hline & $12 \mathrm{~K}$ & $<100$ & $49+/-11$ & $94+/-5$ & $147+/-13$ & 0.63 & 7.9E-04 +/- 6.9E-05 \\
\hline & $25 \mathrm{~K}$ & $<100$ & $35+/-8$ & $180+/-12$ & $227+/-17$ & 0.45 & $1.2 \mathrm{E}-03+/-9.1 \mathrm{E}-05$ \\
\hline & OBT & $<100$ & $19+/-2$ & $176+/-4$ & $197+/-6$ & 0.24 & $1.1 \mathrm{E}-03+/-3.0 \mathrm{E}-05$ \\
\hline & 25КОВТ & $<100$ & $18+/-1$ & $275+/-13$ & $301+/-11$ & 0.23 & $1.6 \mathrm{E}-03+/-6.0 \mathrm{E}-05$ \\
\hline & $180 \mathrm{~K}$ & $<100$ & $58+/-3$ & $990+/-52$ & $1046+/-52$ & 0.75 & $5.6 \mathrm{E}-03+/-2.8 \mathrm{E}-04$ \\
\hline
\end{tabular}


Table 2: Results of GLM analyses used to explain the evolution of biomarkers as a function of tritium fish dose rate (3H DR). The table only presents the significant results obtained at D60 and D120. 'positive', 'negative' indicates the trend of the interaction between the biomarker and the parameter explaining its evolution. $\mathrm{p}<0.05$ for all trends indicated.

\begin{tabular}{c|c|c} 
Time & Biomarker & 3H DR \\
\hline \multirow{2}{*}{ D60 } & MN frequency & positive \\
& DNA damages & positive \\
\hline \multirow{2}{*}{ D120 } & DNA damages & positive \\
& LMI & positive \\
& Ros activated level & positive \\
& ROS basal level & positive \\
& ROS index & positive \\
& Brain AChE & negative \\
& & positive
\end{tabular}




\section{References}

Adam-Guillermin C, Pereira S, Della-Vedova C, Hinton T, Garnier-Laplace J (2012): Genotoxic and Reprotoxic Effects of Tritium and External Gamma Irradiation on Aquatic Animals Reviews of environmental contamination and toxicology 220, 67-103

Amara R, Selleslagh J, Billon G, Minier C (2009): Growth and condition of 0-group European flounder, Platichthys flesus as indicator of estuarine habitat quality. Hydrobiologia 627, 87-98

ASN (2010): Livre blanc du tritium - The tritium white paper. http://www.asn.fr/sites/tritium.

Audette-Stuart M, Kim SB, McMullin D, Festarini A, Yankovich TL, Carr J, Mulpuru S (2011): Adaptive response in frogs chronically exposed to low doses of ionizing radiation in the environment. Journal of Environmental Radioactivity 102, 566-573

Audette-Stuart M, Yankovich T (2011): Bystander effects in bullfrog tadpoles. Radioprotection 46, S497-S502

Audette-Stuart M, Ferreri C, Festarini A, Carr J (2012): Fatty acid composition of muscle tissue measured in amphibians living in radiologically contaminated and non-contaminated environments. Radiation Research 178, 173-181

Bado-Nilles A, Betoulle S, Geffard A, Porcher JM, Gagnaire B, Sanchez W (2013): Flow cytometry detection of lysosomal presence and lysosomal membrane integrity in the three-spined stickleback (Gasterosteus aculeatus L.) immune cells: Applications in environmental aquatic immunotoxicology. Environmental Science and Pollution Research 20, 2692-2704

Beaugelin-Seiller K (2016): Effects of soil water content on the external exposure of fauna to radioactive is otopes. Journal of Environmental Radioactivity 151, 204-208

Bogen D, Welford G, White C (1979): Tritium distribution in man and his environment. IAEA-SM-232 75, 567574

CNSC (2008): Standards and Guidelines for Tritium in Drinking Water. CNSC, Ontario, 88 pp

Environment Canada 2011: Biological test method: test of larval growth and survival unsing Fathead minnows

Erickson RC (1971): Effects of chronic irradiation by tritiated water on Poecilia reticulata, the guppy. Radionuclides in ecosystems, vol 2. National Technical Information Service, US Department of Commerce, Springfield

Etoh H, Hyodo-Taguchi Y (1983): Effects of tritiated water on germ cells in medaka embryos. Radiation Research 93, 332-339

European_Union (2013): COUNCIL DIRECTIVE 2013/51/EURATOM of 22 October 2013 laying down requirements for the protection of the health of the general public with regard to radioactive substances in water intended for human consumption

Festarini A, Shultz C, Stuart M, Kim SB, Ferreri C (2016): Cellular responses to tritium exposure in rainbow trout: HTO- and OBT-spiked feed exposure experiments. CNL Nuclear Review 5, 155-172

Fournier M, Cyr D, Blakley B, Boermans H, Brousseau P (2000): Phagocytosis as a biomarker of immunotoxicity in wildlife species exposed to environmental xenobiotics. American Zoologist 40, 412420

Gagnaire B, Bado-Nilles A, Sanchez W (2014): Depleted Uranium Disturbs Immune Parameters in Zebrafish, Danio rerio: An Ex Vivo/In Vivo Experiment. Archives of Environmental Contamination and Toxicology 67, 426-435

Gagnaire B, Bado-Nilles A, Betoulle S, Amara R, Camilleri V, Cavalié I, Chadili E, Delahaut L, Kerambrun E, Orjollet D, Palluel O, Sanchez W (2015a): Former uranium mine-induced effects in caged roach: a multiparametric approach for the evaluation of in situ metal toxicity. Ecotoxicology 24, 215-231

Gagnaire B, Cavalié I, Pereira S, Floriani M, Dubourg N, Camilleri V, Adam-Guillermin C (2015b): External gamma irradiation-induced effects in early-life stages of zebrafish, Danio rerio. Aquatic Toxicology $169,69-78$

Gagnaire B, Adam-Guillermin C, Festarini A, Cavalié I, Della-Vedova C, Shultz C, Kim SB, Ikert H, Dubois C, Walsh S, Farrow F, Beaton D, Tan E, Wen K, Stuart M (2017): Effects of in situ exposure to tritiated natural environments: A multi-biomarker approach using the fathead minnow, Pimephales promelas. Science of the Total Environment 599-600, 597-611

Garnier-Laplace J, Della-Vedova C, Andersson P, Copplestone D, Cailes C, Beres ford NA, Howard BJ, Howe P, Whitehouse P (2010): A multi-criteria weight of evidence approach for deriving ecological benchmarks for radioactive substances. J. Radiol. Prot. 30, 215-233

Hagger JA, Atienzar FA, Jha AN (2005): Genotoxic, cytotoxic, developmental and survival effects of tritiated water in the early life stages of the marine mollusc, Mytilus edulis. Aquatic Toxicology 74, 205-217

HPA (2007): Review on risks from tritium. Report from the independent advisory group on ionizing radiations. Documents of the Health Protection Agency Radiation, chemical and environmental hazards, RCE-4

Hunt J, Bailey T, Reese A (2009): The human body retention time of environmental organically bound tritium. J. Radiol. Prot. 29, 23-36 
Hyodo-Taguchi Y, Etoh H (1986): Effects of tritiated water on germ cells in medaka. II. Diminished reproductive capacity following embryonic exposure. Radiation Research 106, 321-330

Hyodo-Taguchi Y, Etoh H (1993): Vertebral malformations in medaka (teleost fish) after exposure to tritiated water in the embryonic stage. Radiation Research 135, 400-404

Hyodo Taguchi Y, Egami N (1977): Damage to spermatogenic cells in fish kept in tritiated water. Radiation Research 71, 641-652

Ichikawa R, Suyama I (1974): Effects of tritiated water on the embryonic development of two marine teleosts. Bull Jpn Soc Sci Fish 40, 819-824

ICRP (2008): ICRP Publication 108. Environmental Protection: The Concept and Use of Reference Animals and Plants. Ann ICRP 37, 1-242

Jaeschke BC, Millward GE, Moody AJ, Jha AN (2011): Tissue-specific incorporation and genotoxicity of different forms of tritium in the marine mussel, Mytilus edulis. Environmental Pollution 159, 274-280

Jha AN, Dogra Y, Turner A, Millward GE (2005): Impact of low doses of tritium on the marine mussel, Mytilus edulis: Genotoxic effects and tissue-specific bioconcentration. Mutation Research - Genetic Toxicology and Environmental Mutagenes is 586, 47-57

Jha AN, Dogra Y, Turner A, Millward GE (2006): Are low doses of tritium genotoxic to Mytilus edulis? Marine Environmental Research 62, S297-S300

Kerambrun E, Henry F, Courcot L, Gevaert F, Amara R (2012): Biological responses of caged juvenile sea bass (Dicentrarchus labrax) and turbot (Scophtalmus maximus) in a polluted harbour. Ecological Indicators 19, 161-171

Kim SB, Shultz C, Stuart M, McNamara E, Festarini A, Bureau DP (2013): Organically bound tritium (OBT) formation in rainbow trout (Oncorhynchus mykiss): HTO and OBT-spiked food exposure experiments. Applied Radiation and Isotopes 72, 114-122

Kim SB, Shultz C, Stuart M, Festarini A (2015): Tritium uptake in rainbow trout (Oncorhynchus mykiss): HTO and OBT-spiked feed exposures simultaneously. Applied Radiation and Isotopes 98, 96-102

Le Guernic A, Sanchez W, Bado-Nilles A, Palluel O, Turies C, Chadili E, Cavalié I, Delahaut L, AdamGuillermin C, Porcher JM, Geffard A, Betoulle S, Gagnaire B (2016): In situ effects of metal contamination from former uranium mining sites on the health of the three-spined stickleback (Gasterosteus aculeatus, L.). Ecotoxicology 25, 1234-1259

Melintescu A, Galeriu D (2011): Dynamic model for tritium transfer in an aquatic food chain. Radiat. Environ. Biophys. 50, 459-473

Melintescu A, Galeriu D, Kim SB (2011): Tritium dynamics in large fish - a model test. Radioprotection 46, S431-S436

Mothersill C, Smith RW, Heier LS, Teien HC, Land OC, Seymour CB, Oughton D, Salbu B (2014): Radiationinduced bystander effects in the Atlantic salmon (salmo salar L.) following mixed exposure to copper and aluminum combined with low-dose gamma radiation. Radiat. Environ. Biophys. 53, 103-114

Nawar WW (1973): The effects of ionizing radiation on lipids. Progress in the Chemistry of Fats and Other Lipids 13, 89-118

O'Neill-Mehlenbacher A, Kilemade M, Elliott A, Mothersill C, Seymour C (2007): Comparison of direct and bystander effects induced by ionizing radiation in eight fish cell lines. International Journal of Radiation Biology 83, 593-602

OPG (2017): ONTARIO POWER GENERATION. Environmental Emissions Data for Darlington Nuclear. OPG, $7 \mathrm{pp}$

Paquet F, Harris on J (2018): ICRP Task Group 95: internal dose coefficients. Ann ICRP 47, 63-74

Parisot F, Bourdineaud JP, Plaire D, Adam-Guillermin C, Alonzo F (2015): DNA alterations and effects on growth and reproduction in Daphnia magna during chronic exposure to gamma radiation over three successive generations. Aquatic Toxicology 163, 27-36

R_Core_Team (2017): R: A language and Environment for Statistical Computing. https://www.R-project.org/, Vienna, Austria

Real A, Sundell-Bergman S, Knowles JF, Woodhead DS, Zinger I (2004): Effects of ionising radiation exposure on plants, fish and mammals: Relevant data for environmental radiation protection. J. Radiol. Prot. 24, A $123-\mathrm{A} 137$

Richetti SK, Rosemberg DB, Ventura-Lima J, Monserrat JM, Bogo MR, Bonan CD (2011): Acetylcholinesterase activity and antioxidant capacity of zebrafish brain is altered by heavy metal exposure. NeuroToxicology 32, 116-122

RStudio_Team (2015): RStudio: Integrated Development for R. RStudio, Inc. http://www.rstudio.com, Boston, MA URL

Sanchez W, Palluel O, Meunier L, Coquery M, Porcher JM, A $\tilde{A}^{-}$t-A $\tilde{A}^{-}$ssa S (2005): Copper-induced oxidative stress in three-spined stickleback: Relationship with hepatic metal levels. Environmental Toxicology and Pharmacology 19, 177-183 
Sanchez W, Porcher JM (2009): Fish biomarkers for environmental monitoring within the Water Framework Directive of the European Union. TrAC - Trends in Analytical Chemistry 28, 150-158

Sazykina TG, Kryshev AI (2003): EPIC database on the effects of chronic radiation in fish: Russian/FSU data. Journal of Environmental Radioactivity 68, 65-87

Smith JT, Bowes MJ, Denison FH (2006): Modelling the dispersion of radionuclides following short duration releases to rivers: Part 1. Water and sediment. Science of the Total Environment 368, 485-501

Smith RW, Moccia RD (2001): The Radiation Induced Bystander Effect: Is there Relevance for Aquaculture? Annals of Aquaculture and Research 3, 1026-1029

Soldatov AA (2005): Peculiarities of organization and functioning of the fish red blood system. Journal of Evolutionary Biochemistry and Physiology 41, 272-281

Strand JA, Fujihara MP, Poston TM, Abernethy CS (1982): Permanence of suppression of the primary immune response in rainbow trout, Salmo gairdneri, sublethally exposed to tritiated water during embryogenesis. Radiation Research 91, 533-41

Stuart M, Festarini A, Schleicher K, Tan E, Kim SB, Wen K, Gawlik J, Ulsh B (2016): Biological effects of tritium on fish cells in the concentration range of international drinking water standards. International Journal of Radiation Biology 92, 563-571

Suyama I, Etoh H, Maruyama T, Kato Y, Ichikawa R (1981): Effects of ionizing radiation on the early development of Oryzias eggs. J. RADIAT. RES. 22, 125-133

Whyte SK (2007): The innate immune response of finfish - A review of current knowledge. Fish \& Shellfish Immunology 23, 1127-1151 